Revue Française de Civilisation Britannique

\title{
Public Services in the UK: the Ongoing Challenges of Delivery and Public Accountability
}

Introduction

\section{Emma Bell, Clémence Fourton and Nicholas Sowels}

\section{OpenEdition}

Journals

Electronic version

URL: https://journals.openedition.org/rfcb/7803

DOI: $10.4000 /$ rfcb.7803

ISSN: 2429-4373

Publisher

CRECIB - Centre de recherche et d'études en civilisation britannique

\section{Electronic reference}

Emma Bell, Clémence Fourton and Nicholas Sowels, "Public Services in the UK: the Ongoing

Challenges of Delivery and Public Accountability", Revue Française de Civilisation Britannique [Online]

XXVI-2 | 2021, Online since 05 January 2021, connection on 04 January 2022. URL: http://

journals.openedition.org/rfcb/7803 ; DOI: https://doi.org/10.4000/rfcb.7803

This text was automatically generated on 4 January 2022 .

\section{(c) $(1)$}

Revue française de civilisation britannique est mis à disposition selon les termes de la licence Creative Commons Attribution - Pas d'Utilisation Commerciale - Pas de Modification 4.0 International. 


\title{
Public Services in the UK: the Ongoing Challenges of Delivery and Public Accountability
}

Introduction

\author{
Emma Bell, Clémence Fourton and Nicholas Sowels
}

1 This special edition of the French Journal of British Studies was prompted by the eruption of a number of scandals concerning private companies involved in the running of public services in the UK, notably the liquidation of Carillion in January 2018. Carillion was a multinational construction and facilities management services company based in Wolverhampton, employing 19,000 people in the UK alone. It was heavily involved in the provision of public services in Britain, such as building infrastructure and hospitals, maintaining prisons, providing school meals and defence accommodation - it is estimated that its work for the UK government accounted for $38 \%$ of its declared revenue in $2016 .{ }^{1}$ When the company was liquidated, there were significant costs, not just to the thousands of people who lost their jobs, but also to the British taxpayer, as the government was forced to pay out just under $£ 150$ million in order to keep essential services running. ${ }^{2}$ Ultimately, it is the State that remains, and is expected to remain, responsible for public service delivery and to guarantee the smooth functioning of regulatory mechanisms so that there is accountability between service providers and users. In the case of Carillion, a House of Commons Report found that the company's governance suffered from "a chronic lack of accountability and professionalism". ${ }^{3}$ Yet the existing legislative and regulatory framework was inadequate to respond to, or even to pick up on, these problems. How was it possible for such a large company and government contractor to go into compulsory liquidation, despite concerns having been raised about its finances as early as 2015? Why were the firm's financial weaknesses not exposed and acted upon, notably by the regulators? Why did public organisations and officials continue to pass the company contracts?

2 The papers in this collection do not specifically analyse the case of Carillion. But they do focus on private sector involvement in the provision of public services in a range of 
different areas, from probation to education and social housing through to infrastructure building, energy and regulation. As a result, they provide some insight into the way systems of regulation and accountability function in the UK, thus giving some answers as to why these often prove inadequate. Indeed, the Carillion incident was not isolated but is rather representative of wider systemic problems: in the words of the House of Commons report on the subject, "Carillion could happen again, and soon". ${ }^{4}$ Carillion was but one further instalment in a litany of failures and scandals affecting private providers of public services in recent years, leading to considerable losses to the public purse and/or seriously affecting service delivery, as well as failing on accountability standards. The UK government's bail-out and then renationalisation of the Stagecoach/Virgin East Coast rail franchise for passenger transport has also been highly controversial, while the flagship project of creating a high-speed rail link between London and the north of England (HS2) risks huge delays and cost over-runs. ${ }^{5}$ Atos, Capita and G4S have also come under public scrutiny for failing to fulfil their contracts adequately, accused of incompetence, fraud and serious social harm, notably in the field of welfare provision. ${ }^{6}$ Yet they continue to be regarded by British officials as viable outsourcing options. In particular, British governments keep resorting to a spatial division of markets such as asylum seeker housing, welfare-to-work schemes, or rail, in which a small number of large companies reap the benefits of State-sanctioned market opening.

\section{The Challenges of Delivery}

3 Alongside increasing private-sector involvement in public services, there has been a simultaneous rise of performance monitoring, driven by the move to New Public Management (NPM), whereby managerial practices from the private sector were transferred to the public sector. From the 1980s onwards, and especially in the wake of John Major's Citizen's Charter, public services have been encouraged to adopt evaluative measures such as Key Performance Indicators (KPIs), commonly used by private companies, in order to demonstrate their efficiency and facilitate public accountability. In an attempt to move from an ethos of bureaucratic paternalism, whereby the State and its agents determine what is in the best interests of service users, successive neoliberal governments have sought to render public services more consumer-focussed, notably through evaluative mechanisms aimed at measuring satisfaction - often in a quantitative way. Service quality is considered to be an essential element of performance measurement using survey-based instruments. It is increasingly regarded as one indicator of competitive performance, yet the notion of quality is by no means straightforward:

The practice of quality management... is characterised by tensions between different definitions of quality, diverse attempts to 'speak for' the user/consumer and uneasy compromises between professional attempts to define quality and the creation of bureaucratic systems (and empires) which regulate quality. ${ }^{7}$

Indeed, there is no agreed definition of what might constitute a measurement of quality in public services and it may differ significantly depending on whether we examine quality from the perspective of users or providers of services. For example, Françoise Granoulhac shows here how school buildings built under Private Finance Initiative schemes are subject to heated debate regarding their "quality". Whereas buildings can be said to be of good architectural quality, this criterion does not necessarily match the 
lived experience of the people actually using the buildings on a daily basis, for whom issues such as the amount of natural light available, or more generally the ergonomics of their workplace are paramount.

That said, quality in public services might commonly be understood as encompassing some or all of the following elements: accessibility, competence, integrity, reliability, responsiveness and safety. ${ }^{8}$ These may be incompatible. For example, a number of the contributors to this special issue highlight the problems of safety that negatively impact on the quality of service provision. David Fée, for instance, notes the failure of private contractors providing public housing to refugees to meet KPIs regarding health and safety issues. Steve Tombs documents the catastrophic consequences of local authorities' safety oversights in the tragic case of the Grenfell tower fire, leading to a breakdown of social protection. Lucie de Carvalho focuses on the failure of regulatory mechanisms vis-à-vis private energy providers to respect climate transition targets and thus protect public health by mitigating the damaging effects of pollution. She also emphasises an interesting clash between different public interests. Whilst it may be in the public interest to reduce pollution for health and safety reasons and to tackle climate change, doing so may threaten another aspect of service quality, namely value for money. Significantly, the Electricity Act of 2010 effectively rendered consumer interests to access cheap energy subservient to the need to reduce greenhouse gas emissions and guarantee a reliable supply of electricity.

Pierre Wokuri examines one, interesting alternative for trying to square the circle of these conflicting interests through the development of community energy groups. These emerged notably during the 2010s as alternative suppliers of electricity from renewable resources. They are community-led, controlled and owned, and have the twofold advantage not just of promoting renewable energy but also getting citizens involved locally in the production and distribution of electricity. However, their impact has remained limited on the whole, as they remain squeezed between the dominant State and market mechanisms which provide the bulk of the UK's electricity. More generally, there are obvious structural reasons why grass-roots, "small is beautiful" alternative systems struggle to provide services which generally rely on vast infrastructures to deliver to minimum guaranteed services to entire populations.

\section{The Challenges of Accountability}

\section{Defining accountability}

7 The discrepancies that may arise between policy objectives and outcomes raise the question of accountability for the delivery of public services. Here again, we run up against a complex notion that is far from being straightforward, both conceptually and politically. Most people assume they know what accountability means, but the term is extremely difficult to define. What does it mean to be accountable? Who is accountable? To whom or what? What for? According to the International Institute for Democracy and Electoral Assistance:

We can say that there is democratic accountability in service delivery when citizens or their representatives question or provide feedback on a public service, and the political actors and service providers either act on that feedback or face consequences. ${ }^{9}$ 

failing companies simply go bankrupt, the notion has a specific meaning in the public domain: firstly, by definition, collective services provided are often essential both to all citizens' day-to-day existence and very survival and to society's smooth functioning. For instance, in the case of the provision of healthcare or clean water, those responsible for providing these services must be held to particularly high standards of probity, given that these services are funded through public money and that any failure to deliver entails huge social liabilities. Moreover, the functioning of public services tends to be all the more difficult to monitor, as continuity of service must be guaranteed and there are strong limits to how market forces can operate. Business failure leading to an end of operations is simply not an option. At a pinch, a hospital or university could be shut. But the same is hardly possible for major rail services or water supplies.

9 Accountability for delivery is therefore essential to the proper functioning of public services, and constitutes a key element of a functioning democracy: if officials fail to fulfil the social contract though the universal provision of quality services at reasonable cost, they can expect to be ejected from public office. Public officials are therefore individually responsible, but accountability also comprises the notion of systemic responsibility: given that individuals are obliged to work within a particular legislative or administrative framework, responsibility must also apply to the overarching system in which they work. ${ }^{9}$ Who is accountable for public service delivery is often difficult to establish: is it the individual public servant - the police officer or the nurse - and/or the minister responsible for the particular government department responsible for ensuring the proper delivery of a particular service, or indeed local authorities, or the government that has failed to guarantee effective mechanisms of accountability? Historically, British government has been based on the principle of ministerial responsibility, as Lucie de Carvalho points out: the Haldane Report from 1918 stated that "the act of every civil servant is [...] regarded as the act of his minister". This principle was later restated during Labour's creation of the welfare state after World War II, in the famous (if probably apocryphal) words of Aneurin Bevan: "The sound of a dropped bedpan in Tredegar Hospital will reverberate round the Palace of Westminster" ${ }^{10}$ But since then, such direct ministerial responsibly has become considerably more difficult to ensure, even if still desirable, given the extent to which the private sector has become involved in public service delivery, thus diffusing real, operational responsibility for delivering services across many organisational levels, and so requiring more varied accountability processes. These questions are not theoretical, but may have substantive legal, material and human implications: Steve Tombs shows here, for example, how in the face of such a lethal accident as the Grenfell Tower fire in June 2017, accountability has been viewed as crucial to social reparation and the application of justice and yet it has been difficult to pinpoint responsibilities for this tragedy.

10 Another complex issue entails determining who exactly providers of public services are accountable to. If we assume that accountability is fundamental to democracy, then these providers are primarily responsible to the demos and to their elected representatives. Again, the issue becomes more complex once private companies are involved, as they are also accountable to their shareholders, which may of course lead to conflicts of interest. This is especially the case when individuals repeatedly pass

Revue Française de Civilisation Britannique, XXVI-2 | 2021 
through the revolving door between the public and the private sectors, a phenomenon particularly common in the energy sector. ${ }^{11}$ Indeed, one study in 2016 revealed that nearly 90 per cent of people leaving the Department for Business, Energy \& Industrial Strategy took up jobs in the energy sector, including six former Energy Ministers. ${ }^{12}$ Furthermore, it is difficult to determine exactly how accountability should be measured. Firstly, what should public service providers be accountable for? It is widely assumed that there are two aspects to accountability here. There is the original, financial, notion of accountability which entails providers submitting themselves to audit and inspection to ensure that money is spent wisely. However, such measurements are not in themselves straightforward, as there may be much conflict over the interpretation of what it means to spend money wisely. Efforts to save money may also of course conflict with the second measure of accountability, namely the quality of service provision. Again, there may of course be disagreement over what constitutes good quality service provision, as highlighted above. Secondly, it is difficult to determine which methods might best ensure accountability: can this be done by instilling a positive culture; by improving transparency; and/or by audit and inspection?

\section{The Challenges to Upholding Accountability}

Perhaps the biggest obstacle to ensuring accountability in public service delivery is that the regulatory mechanisms designed to uphold it are often derided as unnecessary 'red-tape' encouraging excessive bureaucratic control and hindering the freedom of enterprise. In the context of the move towards NPM, it was assumed that the State and the services it provided had often acted unaccountably beforehand. Indeed, the old Morrisonian model of state ownership and control of utilities and services provided the general public with very little say in how those services were delivered and little means of redress should they find them wanting. Incidentally, this is why recent plans advanced by the Labour Party to renationalise utilities proposed more horizontal, participatory forms of ownership and management to facilitate democratic accountability. ${ }^{13}$ On the Right, Margaret Thatcher famously railed against state bureaucracy and believed that privatising utilities and introducing managerialist reforms into public services would improve accountability. Contrary to traditional public sector accountability that was thought to flow upwards between civil servants and politicians who would make paternalistic decisions about what was in the best interests of service users, these reforms were meant to provide service users with more power by allowing them to exercise consumer choice and to participate in user evaluation surveys whereby they could give feedback to providers. ${ }^{14}$

In practice, however, the trend towards the increased involvement of the private sector in the provision of public services has not provided significantly more choice for consumers, nor always improved accountability. As Mary Corcoran points out in her contribution examining the contracting out of probation services, over the past decade there has actually been a trend away from competition towards oligopoly. Whilst the Conservative-Liberal Democrat Coalition government's decision to contract out probation services in 2013 was meant to advance the 'Big Society' agenda by encouraging private and third sector providers to bid for contracts, eight private consortia were awarded all of the twenty-one contracts to run probation services in 
England and Wales. This trend is not confined to probation services, but to public sector contracts more generally. Research by The Financial Times found that in 2018, 23\% of all public sector contracts went to a sole bidder..$^{15}$ Companies such as G4S, Serco and Capita dominate the growing market for outsourcing and contracting which is estimated to cost the UK government $£ 251.5$ billion per year. ${ }^{16}$

Given the market dominance of these actors, it is particularly difficult to hold them to account. The fact that the government has repeatedly awarded them contracts despite obvious failures of service delivery, such as when G4S was found to have charged for electronically monitoring offenders who were in prison or dead, suggests that they, like the banks in 2008, are widely considered to be "too big to fail". Should regulatory regimes be considered too hostile, regardless of whether or not they improve accountability, these multinationals can easily hold the UK government hostage by threatening to move elsewhere ${ }^{17}$. This may go at least some way to explaining what de Carvalho describes in this issue as "the inherently ad hoc and flexible British accountability culture".

A significant accountability problem has also arisen as marketisation processes and private sector interests have seeped into the regulation process itself. Steve Tombs again here notes how Local Authority Environmental Health Officers, charged with upholding food safety, occupational health and pollution control, are now increasingly trained with private sector concerns in mind and complete work placements as part of their training with the principal UK supermarket chains such as Asda, Sainsbury's and Tesco's. Furthermore, private companies are now increasingly involved in the regulation process, notably under the Primary Authority Scheme, initially introduced in 2009. This allows companies operating in a number of regulatory jurisdictions to register with just one local authority which then becomes responsible for its regulation on a national basis. According to Tombs, this considerably weakens the capacity of local authorities to adequately carry out their regulation duties, especially given that many of them apply a light-touch approach out of fear of losing jobs and business for their local area. Under what the Blair government marketed as 'better regulation' but which has actually led to a significant decline of regulatory enforcement, regulation is increasingly about facilitating the actions of private capital rather than regulating it per se. Even when local authorities do seek to impose strict regulations, in many cases, as David Fée points out here, private companies simply opt to pay a fine for breach of contract and carry on business as usual.

Holding private companies to account is further complicated by the fact that there have been simultaneous trends towards marketisation and centralisation, as the State still seeks, often ineffectively, to maintain its regulatory function. As Mary Corcoran notes in her contribution, outsourcing has had the paradoxical effect of "reproduc[ing] and multiply[ing] [state power] through the diffusion of obligatory accountability to greater numbers of agents who carry out public welfare or penal work in the local state or in civil society". Rather than reinforcing accountability, this has instead generated such complexity that regulatory enforcement becomes inefficient. Similarly, de Carvalho argues that the creation of regulatory quangos in the energy sector has created what she describes as "an institutional in-betweenness for accountability", meaning that accountability becomes further removed from both the state and independent regulators. 


\section{Contextual Challenges: Complexity, Democratic Deficits, Brexit, Covid-19 and beyond}

17 The current state of public services and accountability - as presented here - may therefore seem to be unsatisfactory. Yet, it may well be asked if there are simple, overarching conclusions to be drawn about where policy should go. NPM, which is actually now quite old, has many failings, and in its election manifesto in December 2019, Labour did commit itself to bringing rail, mail, water and energy back into public ownership. ${ }^{18}$ It recognised that there cannot be any return to the Morrisonian, vertically-integrated model of nationalised industries implemented after World War II, when Britain on the one hand was a far more disciplined and politically egalitarian society than it is today as a result of the War, while goods and services in both the public and private sectors were far less complex than they are now. In fact, Labour plans for re-nationalisation partly acknowledged these issues de facto, by proposing hybrid structures for new publicly-owned services: e.g. energy industries would be managed by a national agency, as well as regional and municipal agencies. Nevertheless, even leaving aside the cost of the whole project, a short assessment of Labour's proposals, published by the non-partisan Institute of Fiscal Studies, was somewhat sceptical about how much better-run the industries would be. In particular, the authors of the study noted that Labour plans to pursue extra objectives like increasing the number of workers in rail and strengthening renewable energies while "maintain[ing] prices at or below current levels would add additional layers of complexity to this challenge". ${ }^{19}$

18 This issue of complexity is explored here by Nicholas Sowels, in a brief introduction to complexity theory and how it relates to public services. Put at its most simple, complexity theory draws on developments in natural sciences which go beyond Newtonian physics and its strong, predictable causalities to understand how the various elements of complex systems may interact in variable and sometimes unpredictable ways. Such analyses in natural sciences have been progressively applied to social sciences over the last twenty years, and to public services too, especially as NPM has led to far more complex system architectures compared to the bureaucratic structures which dominated public (and private) organisations for much to the $20^{\text {th }}$ century. Almost by definition, recourse to complexity theory suggests that looking for simple solutions or policy prescriptions to complex issues is unlikely to work particularly well.

19 From a public policy point of view, the notion of rising complexity also has its role to play in the growing democratic deficits which have emerged in liberal democracies in recent decades, and which are one of the contributory causes of national populist reactions, such as the drive to Brexit since 2016. In a special issue of The Political Quarterly on Rethinking Democracy (published in January 2019), leading British political scientists examine the flaws of the British political and economic system which ultimately led to the Brexit vote, ${ }^{20}$ which in turn is perhaps leading to the greatest constitutional upheaval Britain has known since the Glorious Revolution, even threatening the very existence of the Union. Thus, on the issue of accountability that we are examining here, for example, Tony Wright notes that even as markets had "implanted themselves into the public realm", leading to a "sense of control lost and responsibility dissolved", "in many respects the accountability of governments has 
dramatically increased in recent times". ${ }^{21}$ Yet he also goes on to note that "the explosion of accountability that has taken place has not been accompanied by a strengthened attachment to, or trust in, the institutions of democratic government". The sheer increased complexity of public policy has surely a role to play in this paradoxical situation: after all, are we - even as informed readers - able to assess the merits of extending the working lives of nuclear power plants, say, building third generation pressurised water reactors (as at Flamanville or Hinkley Point), or pulling out of nuclear energy rapidly, given its low carbon emissions? And what of the people we send to Parliament or the Assemblée Nationale to represent us? Indeed, for Wright, it would help if politicians were more open about the limits of what they can do.

More generally, greater complexity surely also has its role to play in the widelydiscussed gap that has emerged between internationally integrated "elites" and "left behind" populations. In Vernon Bogdanor's contribution on Rethinking Democracy, he states boldly that "[s]ince the 1980s, the British people have made great strides towards citizenship in the economic sphere and in their relationship with public services". ${ }^{22} \mathrm{He}$ attributes this to the extension of share ownership under Thatcher, and the long term impact of John Major's Citizen's Charter, which he claims have improved standards and rights of redress. Yet at the same time, citizens have been "expected to remain passive in their political lives", while the constitutional reforms of the Blair era led to sharing power among the elite, but little transfer of power from the elites to the people. For Bogdanor, the future lies especially in injecting direct democracy into the British political system, notably at local government level. For its part, Labour under Jeremy Corbyn did indeed suggest greater citizen involvement in managing public services ${ }^{23}$.

While such institutional and constitutional change may no doubt provide some solutions to aspects of Britain's democratic deficit(s), it ignores the economic and social trends brought on by neoliberalism and globalisation and the fundamental way it has strengthened capital at the expense of labour. Here, Colin Crouch's contribution, building on his work on post-democracy, is more relevant. He too identifies the shift in the "vital energy of the political system", which no longer rests in the institutions of liberal democracy, as it has "disappeared into small private circles of economic and political elites". ${ }^{24}$ In his original arguments on post-democracy, he argued that movements emerging from the population at large are therefore needed to give the system a shock from time to time, raising new questions; and these could be feminism, environmentalism and xenophobic nationalism. In the event, it has been the latter that has triumphed in the UK (and in the US), as questions of migration, the "added frisson of occasional acts of Islamic terrorism" and "feeling of loss of national control facilitated by globalisation" have "apparently threatened national identities". ${ }^{25}$

So much for some of the causes of Brexit. What now of its consequences for public services? Clémence Fourton here examines how constitutional change in the UK, and especially devolution have affected public services across the nations of the United Kingdom, and how such changes could well be amplified by Brexit. More specifically, she points to the diverging welfare systems that now exist within the UK, as powers for most welfare services have been devolved. She notes that EU membership, on the other hand, has acted to create an overall legal framework which nevertheless ensures a certain homogeneity on the basis of EU social and employment laws, as well as human rights legislation. As Britain will now be repatriating all EU laws, with a view to changing them, Brexit may well lead to further divergence in welfare systems within 
the UK. Tensions may also arise between England and the other nations of the Union should EU social funds and agricultural subsidies not be replaced by domestic programmes. Finally, the Conservatives have specifically weakened their commitments to ensuring that labour rights will remain the same after Brexit, and will most likely undermine protective legislation in line with their penchant for deregulation.

As for the Brexiteers-national populists' record in government so far, it has been a very mixed bag indeed. At the time of writing (late summer 2020), the Chancellor of the Exchequer, Rishi Sunak, seems to be having a good Covid-19 crisis, and has generally been applauded for providing massive and rapid financial support to households and businesses. Otherwise, the Johnson government is not deemed to have handled the Covid-19 crisis especially well so far, with policies often seeming to be inconsistent and involving U-turns. The " $\mathrm{A}$ " levels fiasco too suggests considerable incompetence by the government, while its sacking of the senior civil servant at the Department of Education reveals an unwillingness to take responsibility for its actions on the one hand, and provides further evidence of the apparent upheaval which Downing Street is planning for the civil service on the other hand. More generally, according to Martin Wolf (chief economics commentator of The Financial Times), Johnson's team, as populists elsewhere, pursues politics more as a matter of performance than as a question of government, for which they care little. ${ }^{26}$ Quite how the Conservatives under Johnson will act to improve public services, especially in the light of Brexit and as Covid-19 rolls on, remains to be seen, and whether they succeed may well be doubted.

It is of course impossible to know what the lasting impact of the "coronacrisis" will be on our societies and public services, in the UK and worldwide. For all the talk of emerging from Covid-19 with a different set of political, social and economic priorities - say to fight global warming, defend biodiversity, combat plastic pollution and perhaps reduce inequalities in recognition of the importance of "front line" workers there will most likely be an overwhelming attempt to get back to business as usual: just as there was after the financial crisis and Great Recession in 2007-2009. Yet the immediate impact of the crisis has been to see governments intervene absolutely massively to support households and businesses - for the time being. The macroeconomic policy environment has changed significantly in many ways, as interest rates are likely to remain low for the foreseeable future, giving governments much more leeway to maintain active policies. The current health situation also reminds us that States are what we turn to in times of crises, and that accountability is not the priority when institutions need to be urgently adapted to fast-changing circumstances: indeed, accountability seems to be an after-thought, rather than built in to structures and processes in the first place. Yet, as this issue indicates, there are always further ways of institutionalising accountability. The longer the Covid-19 crisis goes on, the greater the challenges to public policies and services will be and more will likely be demanded of government. Enhancing accountability will surely be one vital component to ensuring that greater State action remains compatible with the largelyopen and pluralistic societies of today's liberal democracies. 


\section{BIBLIOGRAPHY}

Bjuremalm, Helena, Fernández, Alberto, Jorge, Gibaja and Molleda, Valladares Democratic Accountability in Service Delivery A practical guide to identify improvements through assessment, International Institute for Democracy and Electoral Assistance (2014), <https://www.idea.int/ sites/default/files/publications/democratic-accountability-in-service-delivery.pdf> [10 July 2020].

Bogdanor, Vernon, “Constitutional Reform: Death, Birth and Renewal”, in Gamble, Andrew and Wright, Tony (eds), Rethinking Democracy, Volume 91, Issue S1, The Political Quarterly, January 2019: 47-61.

Crossman, Sam, Emerson, Carl and Kraftman, Lucy, Labour's Nationalisation Policy, IFS Briefing No BN271, 3 December 2019.

Crouch, Colin, Post-Democracy (Cambridge, Policy Press, 2012 [2004]).

Democracy and Electoral Assistance (2014), <https://www.idea.int/sites/default/files/ publications/democratic-accountability-in-service-delivery.pdf> [10 July 2020].

Clarke, John and Newman, Janet, The Managerial State, (London, Sage, 2006 [1997]).

Crouch, Colin, "Post-Democracy and Populism", in Gamble, Andrew and Wright, Tony (eds), Rethinking Democracy, Volume 91, Issue S1, The Political Quarterly, January 2019:124-137.

Gamble, Andrew and Wright, Tony (eds), Rethinking Democracy, Volume 91, Issue S1, The Political Quarterly, January 2019.

House of Commons, Carillion Report, HC 769 (May, 2018), <https://publications.parliament.uk/pa/ cm201719/cmselect/cmworpen/769/769.pdf> [10 July 2020].

House of Commons Committee of Public Accounts, Contracting out public services to the private sector, 26 February 2014, <https://publications.parliament.uk/pa/cm201314/cmselect/ cmpubacc/777/777.pdf $>$ [1September 2020]

House of Commons Public Administration and Constitutional Affairs Committee, After Carillion: Public sector outsourcing and contracting, 3 July 2018, <https://publications.parliament.uk/pa/ cm201719/cmselect/cmpubadm/748/748.pdf> [21 July 2020].

Kay, John, “An apt misquotation can reveal the greater truth", The Financial Times, 29 December 2015.

Labour Party, Alternative Models of Ownership, 2017, <https://labour.org.uk/wp-content/uploads/ 2017/10/Alternative-Models-of-Ownership.pdf> [10 July 2020].

Labour Party Manifesto 2019, It's time for a real change, 2019.

MORI Review for the Office of Public Service Reform, 2002, <https://www.ipsos.com/sites/default/ files/publication/1970-01/sri_local_gov_public-

service_reform_measuring_and_understanding_customer_satisfaction_042002.PDF> [1

September 2020].

Murphy, Peter, Ferry, Laurence, Glennon, Russ and Greenhalgh, Kirsten, Public Service Accountability: Rekindling a debate (Basingstoke, Palgrave Macmillan, 2019).

NAO, High Speed Two: A Progress Update, report by the Comptroller and Auditor General, 24 January 2020, <https://www.nao.org.uk/report/high-speed-two-a-progress-update/> [3 September 2020]. 
Plimmer, Gill, "Sole outsource bidders win more public sector contracts", The Financial Times, 13 January 2019.

Prime Minister's Office of Public Service Reform, Measuring and Understanding Consumer Satisfaction: A Leeson, Josh, University of Bath dissertation, Keeping the Revolving Door Spinning: Is the Advisory Committee on Business Appointments Fit for Purpose?, April 2016.

White, Alan, Who Really Runes Britain? (London, Oneworld Publications, 2017).

Wolf, Martin, “Will Covid-19 end populism?", video comment, The Financial Times, 13 August 2020, at <https://www.ft.com/video/1d5916ab-66b9-44ef-8528-804f518837f0> [1 September 2020].

Wright, Tony, "Democracy and its discontents", in Gamble, Andrew and Wright, Tony (eds), Rethinking Democracy, Volume 91, Issue S1, The Political Quarterly, January 2019: pp. 5-17.

\section{NOTES}

1. House of Commons, Carillion Report, HC 769 (May, 2018) p. 8, <https:// publications.parliament.uk/pa/cm201719/cmselect/cmworpen/769/769.pdf> [10 July 2020].

2. Ibid, p. 3.

3. Ibid, p. 88 .

4. Ibid, p. 5.

5. NAO, High Speed Two: A Progress Update, report by the Comptroller and Auditor General, 24 January 2020, <https://www.nao.org.uk/report/high-speed-two-a-progress-update/> [3 September 2020].

6. House of Commons Committee of Public Accounts, Contracting out public services to the private sector, 26 February 2014, <https://publications.parliament.uk/pa/cm201314/cmselect/ cmpubacc/777/777.pdf> [1September 2020]; Alan White, Who Really Runes Britain? (London, Oneworld Publications, 2017).

7. John Clarke and Janet Newman, The Managerial State, (London, Sage, 2006 [1997]), p. 120.

8. Prime Minister's Office of Public Service Reform, Measuring and Understanding Consumer Satisfaction: A MORI Review for the Office of Public Service Reform, 2002, <https://www.ipsos.com/ sites/default/files/publication/1970-01/sri_local_gov_public-

service_reform_measuring_and_understanding_customer_satisfaction_042002.PDF>

September 2020].

9. Helena Bjuremalm, Alberto Fernández, Gibaja Jorge and Valladares Molleda, Democratic Accountability in Service Delivery A practical guide to identify improvements through assessment, International Institute for Democracy and Electoral Assistance (2014), p.18, <https:// www.idea.int/sites/default/files/publications/democratic-accountability-in-servicedelivery.pdf> [10 July 2020].

10. John Kay, "An apt misquotation can reveal the greater truth", The Financial Times, 29 December 2015.

11. See Peter Murphy, Laurence Ferry, Russ Glennon and Kirsten Greenhalgh, Public Service Accountability: Rekindling a debate (Basingstoke, Palgrave Macmillan, 2019), p. 31.

12. Josh Leeson, University of Bath dissertation, Keeping the Revolving Door Spinning: Is the Advisory Committee on Business Appointments Fit for Purpose?, April 2016.

13. Labour Party, Alternative Models of Ownership, 2017, <https://labour.org.uk/wp-content/ uploads/2017/10/Alternative-Models-of-Ownership.pdf> [10 July 2020].

14. Clarke and Newman, op. cit., pp.64-5.

15. Gill Plimmer, "Sole outsource bidders win more public sector contracts", The Financial Times, 13 January 2019. 
16. House of Commons Public Administration and Constitutional Affairs Committee, After Carillion: Public sector outsourcing and contracting, 3 July 2018, <https://publications.parliament.uk/ pa/cm201719/cmselect/cmpubadm/748/748.pdf> [21 July 2020].

17. Colin Crouch, Post-Democracy (Cambridge, Policy Press, 2012 [2004]), p. 32.

18. The Labour Party Manifesto 2019, It's time for a real change, 2019.

19. Sam Crossman, Carl Emerson, Lucy Kraftman, Labour's Nationalisation Policy, IFS Briefing No BN271, 3 December 2019.

20. Andrew Gamble and Tony Wright (eds), Rethinking Democracy, Volume 91, Issue S1, The Political Quarterly, January 2019.

21. Tony Wright, "Democracy and its discontents", in Gamble and Wright, ibid, pp. 5-17.

22. Vernon Bogdanor, “Constitutional Reform: Death, Birth and Renewal”, in Gamble and Wright, ibid, pp. 47-61.

23. Labour Party, 2019, op. cit.

24. Colin Crouch, "Post-Democracy and Populism", in Gamble and Wright, ibid, pp. 124-137.

25. Ibid.

26. Martin Wolf, “Will Covid-19 end populism?", video comment, The Financial Times, 13 August 2020, at <https://www.ft.com/video/1d5916ab-66b9-44ef-8528-804f518837f0> [1 September 2020].

\section{AUTHORS}

EMMA BELL

LLSETI, Université de Savoie Mont Blanc

\section{CLÉMENCE FOURTON}

CECILLE, Sciences Po Lille

\section{NICHOLAS SOWELS}

PHARE, Université Paris I/associate member of CREW, Université Paris3 